\title{
ISOLASI DAN KARAKTERISASI PARSIAL KOLAGEN DARI TERIPANG GAMMA (Stichopus variegatus)
}

\section{Isolation and Partial Characterization of Collagen from Gamma Sea Cucumber (Stichopus variegatus)}

\author{
Yusro Nuri Fawzya ${ }^{1 *}$, Ekowati Chasanah ${ }^{1}$, Achmad Poernomo' dan M.H. Khirzin ${ }^{2}$ \\ 1 Pusat Penelitian dan Pengembangan Daya Saing Produk dan Bioteknologi Kelautan dan Perikanan, \\ JI. K.S. Tubun Petamburan VI, Jakarta Pusat, Indonesia \\ 2 Departemen IImu dan Teknologi Pangan, Fakultas Teknologi Pertanian, \\ Institut Pertanian Bogor, Darmaga, Bogor, Indonesia \\ Korespondensi Penulis: nurifawzya@gmail.com
}

Diterima: 12 Januari 2016; Disetujui: 22 Mei 2016

\begin{abstract}
ABSTRAK
Isolasi dan karakterisasi parsial kolagen dari teripang gamma (Stichopus variegatus) telah dilakukan. Isolasi dilakukan melalui tiga tahap yaitu preparasi, ekstraksi dan isolasi. Tahap preparasi meliputi tahapan penyiangan, pencucian dan perendaman dalam akuades, dalam alkohol, dalam larutan Tris$\mathrm{HCl}$ dan etilenadiaminatetraasetat (EDTA) dan perendaman dalam larutan natrium hidroksida $(\mathrm{NaOH})$. Ekstraksi dilakukan dengan perendaman asam asetat $0,5 \mathrm{M}$. Isolasi dilakukan dengan cara pengendapan menggunakan $\mathrm{NaCl}$ dilanjutkan proses dialisis. Isolat kolagen teripang gamma yang diperoleh memiliki rendemen sebesar 16,40\% (bobot kering), nilai $\mathrm{pH} 6,08$ dan derajat putih 77,02\%. Gugus fungsi kolagen terdiri dari amida A (3412 $\left.\mathrm{cm}^{-1}\right)$, B $\left(2929 \mathrm{~cm}^{-1}\right)$, I $\left(1654 \mathrm{~cm}^{-1}\right)$, II $\left(1554 \mathrm{~cm}^{-1}\right)$, dan III (1239 $\mathrm{cm}^{-1}$ ). Asam amino utama penyusun kolagen yaitu glisin, prolin, dan alanin, masing-masing sebesar 16,88\%; 6,71\%; dan 6,42\%. Kolagen yang dihasilkan merupakan kolagen tipe I, diduga terdiri dari 3 rantai $\alpha_{1}$ yang homolog dengan berat molekul 130,33 kDa.
\end{abstract}

KATAKUNCI: teripang gamma, kolagen, karakterisasi parsial, Stichopus variegatus

\begin{abstract}
Isolation and partial characterization of collagen from gamma sea cucumbers (Stichopus variegatus) has been carried out. Isolation was done through three steps, i.e. preparation, extraction and isolation. Preparation step was dressing, immersing in water, in alcohol, in Tris- $\mathrm{HCl}$ and EDTA, followed by immersing in $\mathrm{NaOH}$ solution. Extraction was done by using $0.5 \mathrm{M}$ acetic acid. Then isolation was conducted through salt precipitation followed by dialysis. The yield of gamma sea cucumber collagen produced was $16.40 \%(\mathrm{db})$, with a $\mathrm{pH}$ value of 6.08 and whiteness $77.02 \%$. Collagen has a functional group of amide $A\left(3412 \mathrm{~cm}^{-1}\right), B\left(2929 \mathrm{~cm}^{-1}\right), I\left(1654 \mathrm{~cm}^{-1}\right), I /\left(1554 \mathrm{~cm}^{-1}\right)$, and III $\left(1239 \mathrm{~cm}^{-1}\right)$. The main amino acid content, were glycine, proline and alanine $(16.88 \%$; $6.71 \%$; and $6.42 \%$ respectively). The collagen produced is type I collagen which might contain of $\left(\alpha_{1}\right)_{3}$ chain with the molecular weight of $130.33 \mathrm{kDa}$.
\end{abstract}

KEYWORDS: gamma sea cucumbers, collagen, partial characterization, Stichopus variegatus

\section{PENDAHULUAN}

Teripang atau timun laut diketahui mengandung zat gizi yang tinggi dan berbagai zat aktif yang memiliki khasiat untuk kesehatan, di antaranya untuk menjaga sistem imun tubuh, menyembuhkan luka, sebagai antioksidan dan manfaat kesehatan lainnya (Bordbar, Anwar \& Saari, 2011). Salah satu bahan aktif yang banyak terkandung dalam teripang adalah kolagen, yang mencapai sekitar $80 \%$. Kolagen merupakan salah satu jenis protein struktural yang tersusun dari asam-asam amino, terutama didominasi oleh asam amino prolin, hidroksi prolin, alanin dan glisin. Kolagen tidak saja diaplikasikan pada produk-produk kesehatan, namun kolagen banyak digunakan juga untuk keperluan kosmetik, di antaranya untuk meningkatkan kelembaban kulit dan mencegah penuaan dini (Silva et al., 2014).

Di Indonesia, kebutuhan kolagen umumnya masih diperoleh dari impor; termasuk gelatin yang merupakan 
produk hidrolisis parsial dari kolagen. Data International Trade Centre (2016) menyebutkan bahwa impor gelatin (termasuk kolagen) ke Indonesia dengan HS code 3503 pada tahun 2015 adalah 4.109 ton dengan nilai mencapai US \$31.741.000. Sumber kolagen dan gelatin komersial umumnya berasal dari sapi atau babi yang perlu diwaspadai kehalalan dan keamanannya terkait dengan kasus penyakit sapi gila (Bovine Spongiform Encephalophaty). Kolagen dari teripang dan hasil perikanan lainnya menjadi alternatif lain yang halal dan relatif aman.

Metode ekstraksi kolagen umumnya didasarkan atas sifat kelarutan kolagen dalam larutan garam netral, asam maupun asam yang ditambah dengan enzim. Sebelum ekstraksi, biasanya dilakukan pre treatment atau preparasi terlebih dahulu untuk menghilangkan pengotor, lemak dan protein non kolagen. Preparasi dapat dilakukan menggunakan alkohol dan larutan asam atau basa encer (Nazeer et al., 2014; Singh, Benjakul, Maqsood, Kishimura, 2011; Silva et al., 2014).

Perkembangan aplikasi kolagen yang semakin luas mendorong penelitian tentang kolagen yang dilakukan secara intensif. Selama kurun waktu 13 tahun (2001-2013) dilaporkan peningkatan publikasi mengenai hasil penelitian kolagen mencapai $170 \%$, sedangkan khusus kolagen dari bahan laut rata-rata mencapai lebih dari $200 \%$ (Silva et al., 2014). Sampai dengan saat ini ketertarikan terhadap eksplorasi kolagen dari bahan laut masih tinggi, karena jenis biota laut yang sangat beragam dan masing-masing dapat memberikan karakteristik kolagen yang berbeda tergantung dari jenis biota/bahan baku, habitat, metode ekstraksinya maupun tujuan aplikasinya. Sebagian besar eksplorasi marine collagen menggunakan bahan baku hasil samping pengolahan ikan, khususnya tulang dan kulit ikan. Penelitian mengenai kolagen teripang masih terbatas, beberapa di antaranya adalah karakterisasi dan komposisi subunit kolagen dari teripang S.japonicus (Cui et al., 2007), ekstraksi dan aplikasi kolagen teripang $S$. hermaniiuntuk pelembab kulit (Andiristanti, 2012), ekstraksi, purifikasi dan karakterisasi kolagen dari teripang Bohadschia bivitatta (Siddiqui, Arief, Yusoff, Suzina, Abdullah, 2013), ekstraksi kolagen dari teripang S.variegatus (Alhana, Suptijah \& Tarman, 2015), aktivitas inhibitor enzim pengubah angiotensin (ACE) dan antioksidan peptida kolagen dari teripang S.variegatus (Khirzin, Sukarno, Yuliana, Fawzya, \& Chasanah, 2015), serta formulasi sediaan krim berbasis nanokolagen teripang gamma (S.variegatus) (Yusida, 2016).

Eksplorasi bahan aktif dari teripang Stichopus di Indonesia akhir-akhir ini meningkat baik yang berbasis kolagen maupun senyawa aktif lainnya, seperti steroid dan saponin (Rasyid, 2014). Hal ini dikarenakan adanya permintaan pasar terhadap produk kosmetik maupun kesehatan berbasis teripang, selain itu ketersediaan jenis teripang Stichopus yang cukup banyak di berbagai perairan Indonesia.

Meskipun eksplorasi kolagen dari teripang gamma (S.variegatus) dalam waktu yang hampir bersamaan dilakukan di beberapa tempat, namun metode ekstraksi yang digunakan berbeda. Penelitian ini dimaksudkan untuk mengisolasi dan mengkarakterisasi kolagen dari teripang gamma ( $S$. variegatus). Informasi dari hasil penelitian diharapkan dapat melengkapi informasi mengenai kolagen dari teripang gamma (S.variegatus), khususnya yang dilakukan oleh Khirzin et al. (2015); maupun peneliti lainnya.

\section{BAHAN DAN METODE}

\section{Bahan}

Bahan baku yang digunakan dalam penelitian ini adalah teripang gamma (Stichopus variegatus) yang diperoleh dalam bentuk segar dari Balai Besar Perikanan Budidaya Laut Lampung. Teripang segar disiangi dan dicuci bersih, kemudian dibawa ke Laboratorium Puslitbang Daya Saing Produk dan Bioteknologi Kelautan dan Perikanan dalam coolbox berisi es. Sebelum dilakukan analisis dan isolasi kolagen, teripang ini telah disimpan beku selama sekitar 7 bulan. Bahan lain yang digunakan untuk isolasi dan analisis kolagen meliputi akuades, Tris$\mathrm{HCl}$, etilenadiaminatetraasetat (EDTA), alkohol, natrium hidroksida $(\mathrm{NaOH})$, asam asetat, natrium klorida, bufer asetat, kantung dialisis (cellulose membrane cut off 14.000), kalium bromida (KBr), asam klorida $(\mathrm{HCl})$, akrilamida, bis-akrilamida, sodium dodesil sulfat (SDS), N,N,N',N'-tetrametiletilendiamina (TEMED), ammonium persulfat (APS), glisin, coomassie brilliant blue (CBB), gliserol, dan betamercaptoethanol (BME).

\section{Alat}

Peralatan yang digunakan meliputi peralatan untuk ekstraksi dan isolasi kolagen (pisau, talenan, gelas beaker, timbangan, magnetic stirrer, refrigerated showcase, refrigerated centrifuge, freeze dryer), serta peralatan/instrumen untuk pengujian/karakterisasi kolagen yaitu oven, tanur, kjeltec, soxhlet, elektroforesis, fourier transform infra redspektrofotometer (Perkin Elmer, Spectrum One), ultra performance liquid choromatography (Waters ACQUITY UPLC ${ }^{\circledR}$ ), $\mathrm{pH}$ meter, dan ColorFlex EZ Hunter Lab. 


\section{Metode}

\section{Preparasi daging teripang}

Teripang beku dicairkan (thawing), dibersihkan, diukur panjang, lebar dan beratnya, kemudian dibelah dan dicuci bersih. Daging teripang selanjutnya dianalisis komposisi kimianya (AOAC 2005).

\section{Isolasi kolagen}

Isolasi kolagen dilakukan melalui tahapan ekstraksi terlebih dahulu, mengikuti metode Park et al. (2012) yang dimodifikasi. Modifikasi dilakukan dengan menambahkan tahapan perendaman dalam alkohol untuk menghilangkan lemak. Selain itu penggunaan $\beta$-merkaptoetanol ditiadakan karena bersifat toksik, dan konsentrasi larutan perendam serta waktu perendaman disesuaikan berdasarkan pengamatan selama proses ekstraksi. Seluruh tahapan ekstraksi dilakukan pada kondisi dingin, sekitar $4{ }^{\circ} \mathrm{C}$. Diawali dengan pencucian, daging teripang kemudian dipotong kecil-kecil dan direndam dalam aquades (1:10 b/v) sambil diaduk menggunakan stirrer selama 30 menit, untuk membersihkan daging

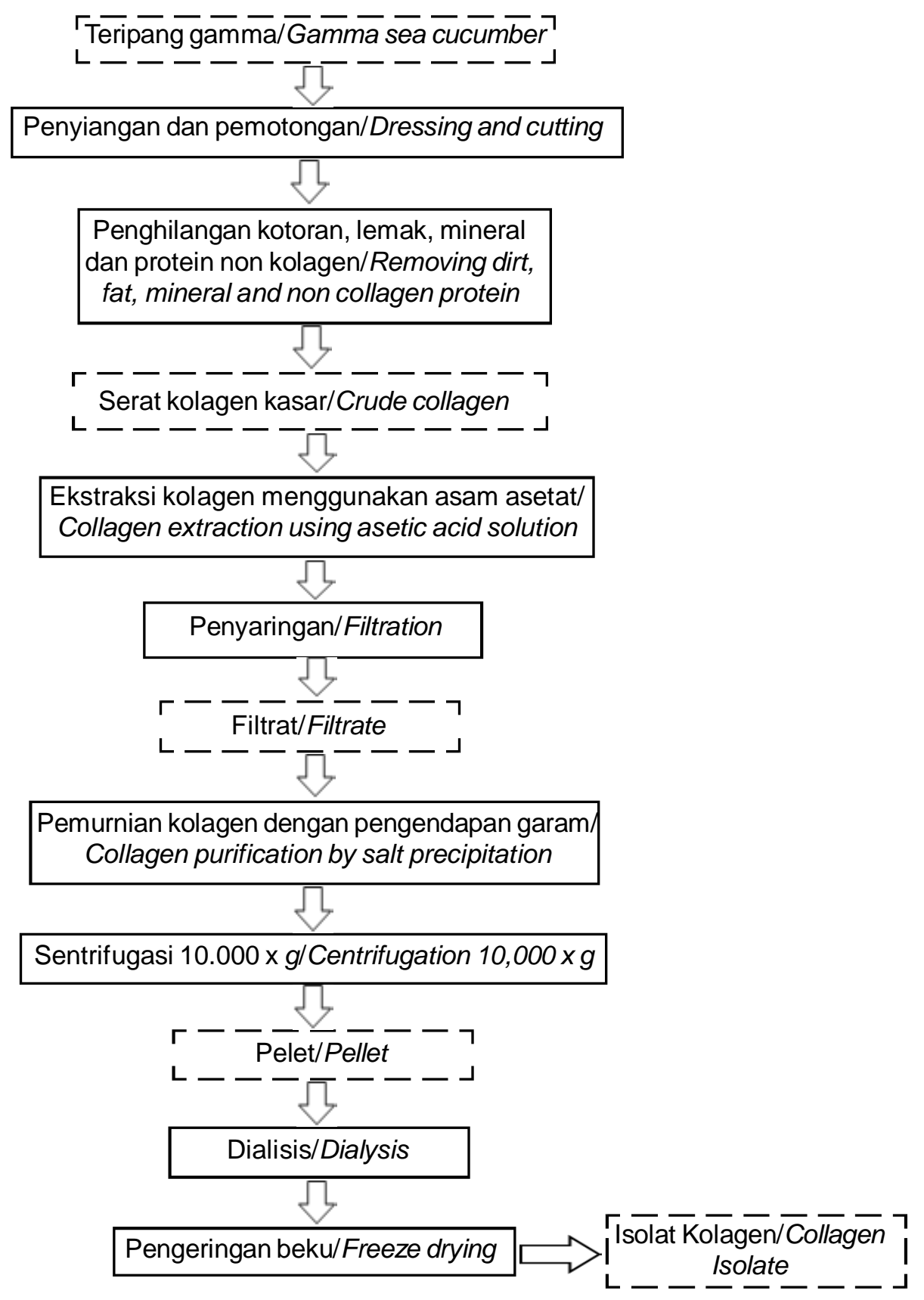

Gambar 1. Diagram alir proses ekstraksi dan isolasi kolagen teripang gamma.

Figure1. Flow chart of extraction and isolation of gamma seacucumber collagen. 
teripang dari sisa-sisa isi perut dan pengotor lainnya. Perendaman aquades dilakukan 2 kali. Berikutnya akuades diganti dengan alkohol 50\% (1:2), diaduk selama 30 menit untuk menghilangkan lemak; lalu dicuci dengan aquades sampai pH netral. Perendaman berikutnya menggunakan 10 bagian volume campuran Tris- $\mathrm{HCl}$ 0,1 M dan 4 mM EDTA, selama 1 malam. Perendaman ini dimaksudkan untuk menjaga stabilitas $\mathrm{pH}$ dan mengurangi mineral. Setelah dicuci dengan akuades, larutan perendam diganti dengan 10 bagian volume $0,1 \mathrm{M} \mathrm{NaOH}$ selama 2 hari, untuk menghilangkan protein-protein non kolagen; kemudian dicuci kembali dengan akuades. Selama perendaman $\mathrm{NaOH}$ sebaiknya dilakukan penggantian dengan larutan $\mathrm{NaOH}$ baru setiap 4-5 jam agar penghilangan protein non kolagen lebih efektif. Perendaman dengan $\mathrm{NaOH}$ diakhiri ketika larutan perendam secara kualitatif tidak mengandung protein, yang dicek menggunakan uji Biuret.

Selanjutnya dilakukan ekstraksi dengan 10 bagian volume asam asetat $0,5 \mathrm{M}$ selama 2 hari, dan disaring menggunakan kain blacu. Filtrat yang mengandung kolagen dilakukan pengendapan garam melalui penambahan garam $\mathrm{NaCl}$ sampai dengan konsentrasi akhir $1 \mathrm{M}$ dan disimpan semalam, kemudian disentrifugasi dengan kecepatan 10.000 x g selama 60 menit. Pelet hasil sentrifugasi dilarutkan dalam asam asetat 0,5 M dan didialisis (kantung dialisis cut off 14.000) dengan bufer asetat 0,1 M selama 1 malam, untuk menghilangkan garam-garam selama proses preparasi dan ekstraksi kolagen. Setiap 4 jam bufer diganti dan terakhir diganti dengan aquades. Selama proses dialisis, dan dengan mengganti cairan/pelarut beberapa kali, molekul garam terdifusi keluar kantong dialisis sehingga protein kolagen yang diperoleh lebih murni. Kolagen murni diperoleh melalui sentrifugasi, sebagai pelet yang kemudian dikeringbekukan. Selanjutnya kolagen yang dihasilkan ditentukan rendemennya, $\mathrm{pH}$, dan derajat putih, serta dilakukan analisis gugus fungsional, asam amino dan bobot molekul. Isolasi kolagen teripang ini dilakukan 2 kali ulangan. Secara garis besar ekstraksi dan isolasi kolagen dari teripang melalui tahapan sebagaimana diagram alir pada Gambar 1.

\section{Analisis dan karakterisasi parsial kolagen}

Kolagen yang dihasilkan diukur rendemennya, yaitu sebagai persentase dari perbandingan antara berat akhir kolagen yang dihasilkan dengan berat awal teripang (dalam \%). Derajat keasaman $(\mathrm{pH})$ larutan kolagen diukur menggunakan $\mathrm{pH}$ meter. Derajat putih diukur menggunakan ColorFlex EZ Hunter Lab.

Analisis gugus fungsional kolagen dilakukan menggunakan alat fourier transform infra red (FTIR) spektrofotometer (Perkin Elmer, spectrum one) berdasarkan metode Barth (2000). Sampel ditambah $\operatorname{KBr}(1: 100)$, lalu dihaluskan hingga tercampur merata. Selanjutnya dilakukan pengepresan dengan pompa vakum selama 15 menit, dan dibaca absorbansinya pada bilangan gelombang $500-3000 \mathrm{~cm}^{-1}$. Dari kurva yang dihasilkan ditentukan jenis ikatan dan gugus fungsionalnya berdasarkan referensi FTIR.

Analisis asam amino dilakukan dengan mengacu pada metode Nollet (1996) dan Waters Acquity UPLC Guide 2012, menggunakan ultra performance liquid chromatography (UPLC). Hidrolisis sampel dilakukan menggunakan $\mathrm{HCl} 6 \mathrm{~N}$ dengan pemanasan $110{ }^{\circ} \mathrm{C}$ selama 22 jam. Sebagai internal standar digunakan $\alpha$-amino butyric acid (AABA), dan sebagai reagen untuk derivatisasi asam amino digunakan AccQ-Fluor reagent kit. Kondisi UPLC adalah sebagai berikut : kolom : ACCQ-Tag Ultra C-18, temperatur : $49{ }^{\circ} \mathrm{C}$, laju alir : 0,5 mL per menit, detektor : photodiode array (PDA), panjang gelombang $260 \mathrm{~nm}$, dan volume injeksi $1 \mu \mathrm{L}$. Sistem elusi dilakukan secara gradien dengan komposisi tertentu. Kadar asam amino dihitung dengan rumus :

$\underset{(\mathrm{mg} / \mathrm{Kg})}{\operatorname{Kadino}}=\frac{\text { luas area puncak sampel } \times \mathrm{C} \text { standar } \times \mathrm{FP} \times \mathrm{BM}}{\text { luas area puncak standar } \times \text { bobot sampel }(\mathrm{g})}$

Keterangan :

$C=$ konsentrasi standar asam amino $(\mu \mathrm{g} / \mathrm{mL})$

$\mathrm{FP}=$ faktor pengenceran

$\mathrm{BM}=$ bobot molekul tiap asam amino $(\mathrm{g} / \mathrm{mol})$

Analisis berat molekul kolagen dilakukan dengan SDS-PAGE (Laemmli,1970). Prinsip dasar SDSPAGE ini adalah denaturasi protein oleh natrium dodesil sulfat yang dilanjutkan dengan pemisahan molekul berdasarkan berat molekulnya dengan metode elektroforesis menggunakan gel, dalam hal ini yang digunakan adalah poliakrilamid. Sebagai penanda protein digunakan marker broad range protein ladderdari Thermo scientific.

\section{HASIL DAN BAHASAN}

\section{Ukuran dan Komposisi Kimia Bahan Baku Teripang Segar}

Bahan baku teripang gamma segar yang digunakan (Gambar 2a) memiliki ukuran fisik dan komposisi kimia sebagaimana disajikan pada Tabel 1.

Informasi mengenai komposisi kimia teripang segar sebagai bahan baku pembuatan kolagen perlu diketahui sebagai bahan pertimbangan dalam proses 
Tabel 1. Ukuran fisik dan komposisi kimia teripang gamma segar

Table 1. Gamma sea cucumber size and chemical composition

\begin{tabular}{lc}
\hline \multicolumn{1}{c}{ Ukuran Fisik/Physical size } & Nilai/Score \\
\hline Panjang/length $(\mathrm{cm})$ & $20.7 \pm 4.3$ \\
Lebar/width $(\mathrm{cm})$ & $7.2 \pm 0.3$ \\
Berat/weight $(\mathrm{g})$ & $195.4 \pm 54.6$ \\
\hline Komposisi Kimia/Chemical composition & \\
Kadar air/moisture (\% wb) & $91.19 \pm 0.07$ \\
Kadar abu/ash $(\% \mathrm{db})$ & $40.18 \pm 1.93$ \\
Kadar lemak/fat $(\% \mathrm{db})$ & $2.72 \pm 0.23$ \\
Kadar protein/protein $(\% \mathrm{db})$ & $54.82 \pm 0.68$ \\
\hline
\end{tabular}

ekstraksi kolagen, khususnya penentuan jenis pelarut, konsentrasi ataupun waktu perendaman untuk tujuan penghilangan bahan-bahan non kolagen dari bahan tersebut. Berdasarkan komposisi kimianya, kandungan lemak teripang gamma relatif cukup tinggi (2,72 \% bobot kering atau bk) dibandingkan jenis teripang lainnya yang pernah dilaporkan, yaitu kurang dari 2\% bk (Aydin, Sevgili, Tufan, Emre \& Ko se, 2011; Fawzya, Januar, Susilowati \& Chasanah, 2015; Haider et al., 2015; Vergara \& Rodriguez, 2016; Zhong, Khan \& Shahidi, 2007). Kandungan lemak ini relatif sama dengan yang pernah dilaporkan oleh Alhana et al. (2015) untuk jenis teripang yang sama, yaitu $2,87 \%$ bk. Jenis teripang Stichopus lainnya yang pernah dilaporkan, yaitu $S$. horrens mengandung lemak sekitar 3,04\% bk (Forghani et al., 2012). Kadar abu teripang yang tinggi berkaitan dengan banyaknya spikula mikroskopis dalam lapisan dermis pada dinding tubuh teripang yang tersusun oleh kalsium karbonat (Hartati, Widianingsih \& Fatimah, 2015; Vergara \& Rodríguez; 2016). Vergara \& Rodríguez (2016) melaporkan bahwa kadar abu teripang Isostichopus sp. bervariasi antara 3,16-3,81\% berat basah (bb) setara dengan $23,43-24,16 \%$ bk. Dengan demikian teripang S.variegatus yang digunakan mengandung mineral yang cukup tinggi $(40,18 \%$ bk) hampir sama dengan kadar abu S.variegatus yang dilaporkan oleh Alhana et al. yaitu 43,18\%.

\section{Rendemen}

Rendemen kolagen teripang gamma ( $S$. variegatus) larut asam (acid solubilized collagen/ASC) yang dihasilkan sebagaimana dilaporkan oleh Khirzin et al. (2015) adalah sebesar $16,40 \pm 4,81 \%$ (bk). Rendemen yang lebih tinggi dilaporkan oleh Abedin et al. (2013) dan Park et al. (2012); yang menggunakan enzim pepsin untuk mengekstrak kolagen; menghasilkan pepsin solubilized collagen (PSC) dengan rendemen berturut-turut sebesar 26,6\%, dan 21,3\%. Bahkan Siddiqui et al. (2013) menemukan rendemen PSC yang sangat tinggi yaitu $65 \%$ (bk), yang dihasilkan dari teripang Bohadschia spp. Rendahnya rendemen ASC diduga karena larutan asam asetat $0,5 \mathrm{M}$ belum mampu melarutkan secara sempurna kolagen teripang yang diekstrak; sebagaimana dilaporkan oleh Jongjareonrak, Benjakul, Visessanguan, dan Tanaka (2005) di dalam Singh et al. (2011) yang menemukan bahwa ekstraksi kolagen kulit ikan mata goyang (Priacanthus macracanthus atau big eye snapper) menggunakan asam setat $0,5 \mathrm{M}$ menghasilkan solubilisasi kolagen yang belum sempurna. Menurut Zhang et al. (2007) molekul kolagen saling berikatan silang baik di dalam maupun di antara molekulmolekul kolagen melalui ikatan kovalen. Ikatan silang ini terbentuk melalui kondensasi gugus aldehid pada daerah telopeptida; sehingga berpengaruh terhadap menurunnya kelarutan kolagen ASC. Dinyatakan juga bahwa penambahan enzim pepsin dapat meningkatkan kelarutan kolagen, sehingga rendemen yang dihasilkan lebih banyak.

\section{pH}

Kolagen teripang gamma yang dihasilkan memiliki nilai pH 6,08 $\pm 0,04$. Alhana et al. (2015) melaporkan bahwa kolagen teripang S.variegatus memiliki nilai $\mathrm{pH} 7,37$. Meskipun jenis teripang yang digunakan sama dan bahan yang digunakan untuk ekstraksi kolagen sama, yaitu asam asetat, namun konsentrasi maupun suhu ekstraksi yang diterapkan berbeda, sehingga menghasilkan karakteristik kolagen yang berbeda. Beberapa kolagen komersial yang digunakan untuk kosmetik memiliki pH 3,8-4,7 (Peng, Glattauer, Werkmeister \& Ramshaw, 2004). Dinyatakan bahwa nilai pH ini berkaitan dengan kandungan garam/mineral 

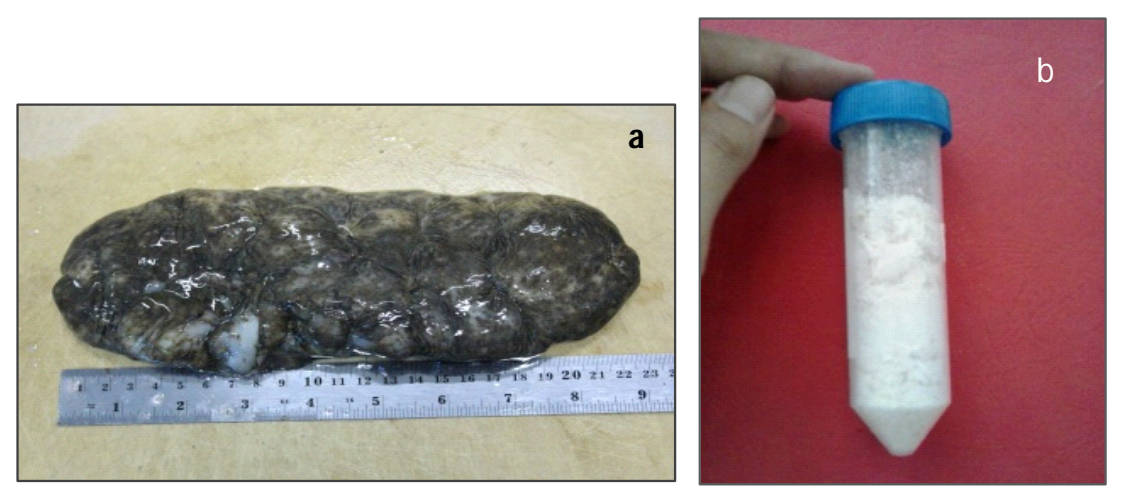

Gambar 2. (a) Teripang gamma (S. variegatus) segar; (b) Kolagen teripang gamma (S. variegatus)

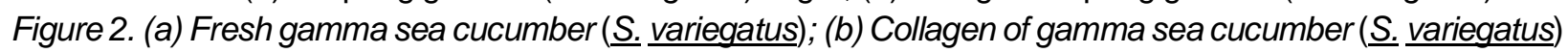

yang berperan sebagai penyangga (buffering) larutan kolagen.

\section{Derajat Putih}

Analisis derajat putih menunjukkan bahwa nilai derajat putih kolagen teripang gamma adalah $77,02 \pm 0,00 \%$. Nilai ini lebih tinggi dari nilai derajat putih teripang gamma yang dilaporkan oleh Alhana et al. (2015), yaitu 69,01\%. Hal ini disebabkan oleh metode ekstraksi yang berbeda. Ekstraksi kolagen teripang gamma yang dilakukan oleh Alhana et al.(2015) menggunakan asam asetat 0,1-0,3\%, dengan pretreatment menggunakan $\mathrm{NaOH} 0,05-$ $0,3 \%$; sedangkan pada penelitian ini menggunakan asam asetat $0,5 \mathrm{M}$ (setara dengan $0,42 \%$ ), dengan pretreatment menggunakan $\mathrm{NaOH} 0,1 \mathrm{M}$ (setara $0,4 \%$ ). Rasio daging teripang dengan pelarut yang digunakan pada kedua riset itu sama. Dengan demikian efektivitas metode ekstraksi kolagen pada penelitian ini lebih tinggi dalam hal mengurangi pigmen sehingga menghasilkan derajat putih yang lebih tinggi daripada metode ekstraksi yang dilakukan oleh Alhana et al. Gambar teripang segar dan kolagennya disajikan pada Gambar 2.

\section{Gugus Fungsional}

Hasil analisis gugus fungsional kolagen teripang gamma menggunakan FTIR menunjukkan bahwa kolagen ini memiliki sebaran puncak-puncak serapan pada beberapa bilangan gelombang yang menunjukkan gugus-gugus fungsional tertentu. Puncak serapan pada bilangan gelombang $3412 \mathrm{~cm}^{-1}$ menunjukkan amida A. Amida ini berada pada kisaran $3400-3440 \mathrm{~cm}^{-1}$, dimana vibrasi $\mathrm{N}-\mathrm{H}$ stretching bebas terjadi (Singh et al., 2011). Puncak serapan amida A dapat bergeser pada frekuensi yang lebih rendah, yaitu $3300 \mathrm{~cm}^{-1}$ apabila gugus $\mathrm{N}-\mathrm{H}$ berikatan dengan ikatan hidrogen (Doyle, Bendit \&
Blout, 1975). Dalam hal ini tidak terdapat gugus NH yang berikatan dengan ikatan hidrogen, karena puncak serapan amida A kolagen teripang gamma ini berada pada $3412 \mathrm{~cm}^{-1}$. Puncak serapan berikutnya terdapat pada panjang gelombang $2929 \mathrm{~cm}^{-1}$, berada pada wilayah serapan amida $B$, yaitu kisaran $2935-2915 \mathrm{~cm}^{-1}$ yang merupakan stretching asimetris dari gugus $\mathrm{CH}_{2}$ (Coates, 2000).

Pada bilangan gelombang $1654 \mathrm{~cm}^{-1}$ ditemukan puncak serapan yang menunjukkan amida I, sebagaimana dinyatakan oleh Singh et al. (2011) bahwa puncak amida I berada pada kisaran bilangan gelombang 1600-1700 $\mathrm{cm}^{-1}$. Puncak tersebut menunjukkan adanya vibrasi $C=O$ stretching di sepanjang rantai polipeptida sekaligus merupakan penanda dari struktur sekunder peptida. Amida II ditemukan pada bilangan gelombang $1554 \mathrm{~cm}^{-1}$. Menurut Kong dan Yu (2007) serapan amida II yang terdapat pada kisaran $1480-1575 \mathrm{~cm}^{-1}$ menunjukkan adanya $\mathrm{C}-\mathrm{N}$ stretching dan $\mathrm{N}$-H bending. Gugus fungsi terakhir adalah amida III dengan puncak serapan pada $1239 \mathrm{~cm}^{-1}$. Kittiphattanabawon, Benjakul, Visessanguan dan Shahidi (2010) menyatakan bahwa amida III memiliki serapan antara $1200-1400 \mathrm{~cm}^{-1}$ yang menunjukkan adanya $\mathrm{N}-\mathrm{H}$ bending dan $\mathrm{C}-\mathrm{H}$ stretching. Analisis gugus fungsional dengan FTIR ini dapat digunakan untuk konfirmasi adanya struktur triple helix, yang diketahui dari nilai rasio serapan amida III (1239 $\mathrm{cm}^{-1}$ ) dengan puncak serapan pada $1450 \mathrm{~cm}^{-1}$ yang mendekati 1 (Plepis et al., 1996 di dalam Silva et al., 2014). Pada Gambar 3 hasil analisis FTIR menunjukkan rasio serapan amida III (pada $1239 \mathrm{~cm}^{-1}$ ) dengan puncak serapan pada $1450 \mathrm{~cm}^{-1}$ menunjukkan nilai yang sesuai dengan pernyataan tersebut, sehingga hal ini menandakan bahwa kolagen teripang ini belum terdegradasi menjadi gelatin karena masih terdapat struktur triple helix. Spektra infra merah kolagen teripang disajikan pada Gambar 3 dan Tabel 2. 


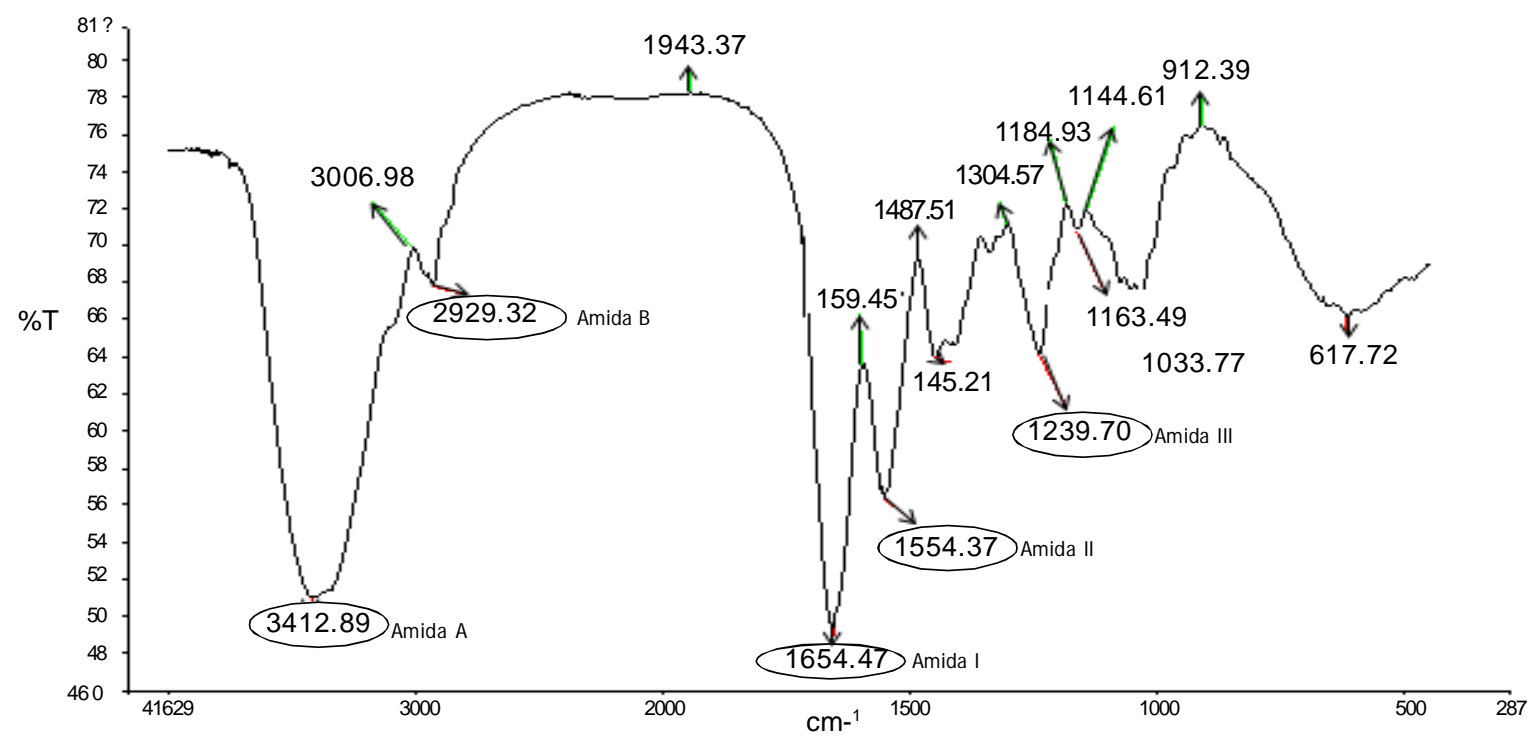

Gambar 3. Spektra infra merah kolagen teripang gamma (S. variegatus).

Figure 3. Infra red spectrum of gamma sea cucumber (‥ variegatus).

Tabel 2. Gugus fungsional kolagen teripang gamma (S. variegatus).

Table 2. Functional group of collagen gamma sea cucumber (․ variegatus).

\begin{tabular}{lccll}
\hline Amida & $\begin{array}{c}\text { Bilangan } \\
\text { Gelombang }\left(\mathbf{c m}^{-1}\right) / \\
\text { Wavenumber }\left(\mathbf{c m}^{-1}\right)\end{array}$ & $\begin{array}{c}\text { Wilayah } \\
\text { Serapan }\left(\mathbf{c m}^{-1}\right) / \\
\text { Wavenumber } \\
\text { Range }\left(\mathbf{c m}^{-1}\right)\end{array}$ & $\begin{array}{c}\text { Keterangan/ } \\
\text { Description }\end{array}$ & \multicolumn{1}{c}{$\begin{array}{c}\text { Referensi/ } \\
\text { References }\end{array}$} \\
\hline Amida A & 3412.89 & $3400-3440$ & N-H stretch & Singh et al., 2011 \\
Amida B & 2929.32 & $2935-2915$ & asimetrikal stretching $\mathrm{CH}_{2}$ & Coates, 2000 \\
Amida I & 1654.47 & $1600-1700$ & C-O stretch & Singh et al., 2011 \\
Amida II & 1554.37 & $1480-1575$ & C-N stretching dan N-H bending Kong dan Yu (2007) \\
Amida III & 1239.70 & $1200-1400$ & N-H bending dan C-H stretching Kittiphattanabawon et al.(2010) \\
\hline
\end{tabular}

Komposisi asam amino kolagen teripang gamma disajikan pada Tabel 3. Hasil analisis menunjukkan bahwa asam amino yang paling dominan adalah glisin $(16,88 \%)$. Hal serupa dilaporkan oleh Alhana et al. (2015), bahwa komposisi asam amino terbanyak dari kolagen teripang S.variegatus adalah glisin (11,35\%). Kolagen dari sumber lainnya juga dilaporkan mengandung asam amino yang didominasi oleh glisin (Jamilah, Umi Hartina, Mat Hashim \& Sazili, 2013; Mahboob, 2015; Singh et al., 2011). Jenis asam amino lainnya yang jumlahnya relatif tinggi adalah asam glutamat $(11,12 \%)$, alanin $(6,42 \%)$ dan prolin $(6,71 \%)$. Struktur triple helix dalam molekul dasar kolagen memiliki susunan asam amino yang khas, yaitu Gly-X-Y, dengan posisi X adalah prolin dan posisi
Y adalah hidroksiprolin. Menurut Aberoumand (2012), kolagen mengandung glisin dalam proporsi sekitar sepertiga bagian, tidak mengandung triptofan dan sistein; dan kadar tirosin dan histidin yang rendah. Pada kolagen teripang gamma ini proporsi glisin masih lebih rendah dari kolagen pada umumnya, meskipun lebih tinggi dari yang dilaporkan Alhana et al.; sedangkan sistein hampir tidak terdeteksi $(0,04 \%)$, dan kadar tirosin dan histidin relatif rendah, yaitu masing-masing 1,20 dan $0,52 \%$. Rendahnya kadar asam amino tirosin, lisin dan histidin pada kolagen teripang juga dilaporkan oleh Abedin et al. (2013) dan Zhong, Chen, Hu dan Ren (2015).

Kadar asam amino kolagen dari jenis bahan baku yang sama bisa saja berbeda, disebabkan oleh 
Tabel 3. Komposisi asam amino kolagen teripang gamma (S. variegatus). Table 3. Amino acid composition of gamma sea cucumber (‥ variegatus).

\begin{tabular}{crl}
\hline Asam amino/Amino acids & Konsentrasi/Concentration (\%) \\
\hline Asp & 5.84 & \pm 0.13 \\
Ser & $2.59 \pm 0.05$ \\
Glu & $11.12 \pm 0.24$ \\
Gly & $16.89 \pm 0.35$ \\
His & $0.52 \pm 0.01$ \\
Arg & $6.57 \pm 0.15$ \\
Thr & $3.73 \pm 0.08$ \\
Ala & $6.42 \pm 0.14$ \\
Cys & $0.04 \pm 0.00$ \\
Tyr & $1.20 \pm 0.02$ \\
Val & $1.82 \pm 0.03$ \\
Met & $0.80 \pm 0.01$ \\
Lys & $0.99 \pm 0.01$ \\
Ile & $1.46 \pm 0.04$ \\
Leu & $2.33 \pm 0.06$ \\
Phe & $1.30 \pm 0.03$ \\
Pro & $6.71 \pm 0.16$ \\
\hline
\end{tabular}

metode ekstraksi yang berbeda, konsentrasi bahan pengekstrak yang berbeda ataupun metode analisis asam amino yang berbeda. Nurhayati, Tazwir dan Murniyati (2013) menemukan bahwa ekstraksi kolagen kulit ikan nila menggunakan asam asetat 1,5 M menghasilkan kadar asam amino sekitar separuh dari kadar asam amino kolagen dari bahan yang sama yang diekstraksi menggunakan asam asetat 0,5M.

\section{Bobot Molekul}

Penentuan bobot molekul kolagen teripang gamma dengan SDS-PAGE sebagaimana dilaporkan oleh Khirzin et al. (2015) menunjukkan nilai bobot molekul (BM) $130,33 \mathrm{kDa}$. Hanya ada satu pita protein dengan nilai tersebut. Menurut Schmidt et al. (2016) terdapat paling tidak 29 jenis kolagen, yang paling umum

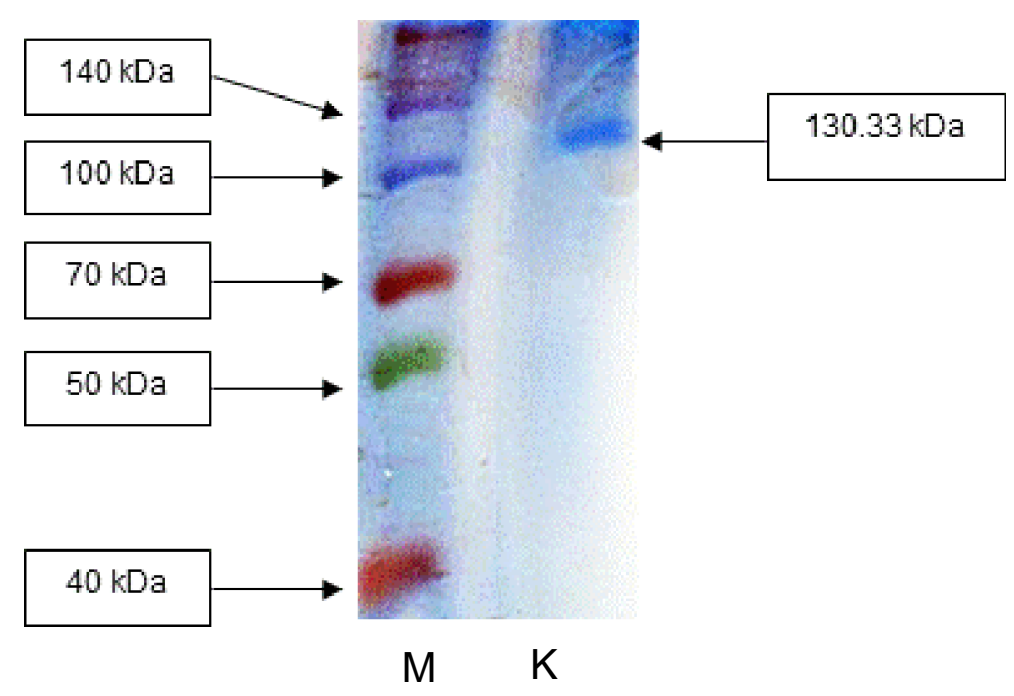

Keterangan/Note: Gambar telah dipublikasi juga oleh Khirzin et al. (2015)

Gambar 4. Elektroforegram SDS-PAGE kolagen teripang gamma (S. variegatus). (M : marker, $\mathrm{K}$ : kolagen).

Figure 4. SDS-PAGE of gamma sea cucumber collagen (‥ variegatus). ( $M$ : marker; $K$ : kolagen). 
adalah kolagen tipe 1, yaitu jenis kolagen yang banyak ditemukan pada jaringan kulit, tendon dan tulang. Kolagen tipe 1 biasanya terdiri dari rantai $\alpha_{1}$ dan $\alpha_{2}$ yang heterolog membentuk triple helix $\left(\alpha_{1}\right)_{2} \alpha_{2}$. Berdasarkan hasil elektroforesis ini diduga bahwa triple helix kolagen teripang ini dibentuk oleh 3 rantai $\alpha_{1}$ yang homolog atau $\left(\alpha_{1}\right)_{3}$. SDS PAGE ini tidak mampu memisahkan rantai $\alpha$, kemungkinan masing-masing rantai $\alpha$ tersebut memiliki sifat kimia dan elektroforesis yang mirip sehingga bermigrasi pada posisi yang sama pada gel, seperti yang dijelaskan oleh Miyauchi dan Kimura di dalam Abedin et al. (2013). Triple helix yang homolog juga ditemukan oleh Abedin et al. untuk kolagen S. vastus dengan BM 122 kDa, Cui et al. (2007) untuk kolagen Stichopus japonicus dengan BM 135 kDa, Liu et al. (2010) untuk kolagen Parastichopus californicus dengan BM $138 \mathrm{kDa}$, dan Zhong et al. (2015) untuk kolagen S. monotuberculatus dengan BM 137 kDa.

Kolagen teripang sebagai salah satu alternatif kolagen sapi atau babi berpotensi untuk dikembangkan sebagai bahan kosmetik atau perawatan kulit (beauty care) maupun aplikasi di bidang kesehatan lainnya (Silva et al., 2014), di antaranya sebagai pelembab, mencegah penuaan dini, pelindung sinar UV dan lain-lain. Meskipun rendemen kolagen teripang relatif kecil, yaitu sekitar $20 \%$ (bk) namun sumberdaya teripang, termasuk Stichopus, tersebar di berbagai wilayah perairan Indonesia (Kiara Indonesia, 2015), termasuk di Pulau Bintan yang saat ini mulai dikembangkan usaha pengolahan teripang sebagai bahan herbal. Menurut Karim \& Bhat (2009) di dalam Zhong et al. (2015), kolagen hewan air dari daerah tropis memiliki kualitas yang serupa dengan kolagen dari hewan darat (sapi dan babi). Oleh karena itu kolagen dari teripang dan hewan air lainnya mempunyai prospek ke depan yang sangat baik untuk dikembangkan.

\section{KESIMPULAN}

Isolasi kolagen teripang gamma (Stichopus variegatus) dengan metode Park et al.(2012) yang dimodifikasi menghasilkan isolat kolagen dengan rendemen 16,40\% (bk), $\mathrm{pH} 6,08$ dan derajat putih $77,02 \%$. Gugus fungsi kolagen terdiri dari amida A $\left(3412 \mathrm{~cm}^{-1}\right)$, B $\left(2929 \mathrm{~cm}^{-1}\right)$, I $\left(1654 \mathrm{~cm}^{-1}\right)$, II $\left(1554 \mathrm{~cm}^{-1}\right)$, dan III $\left(1239 \mathrm{~cm}^{-1}\right)$. Isolat kolagen ini merupakan kolagen tipe 1 yang kemungkinan dibentuk oleh 3 rantai $\alpha_{1}$ yang homolog, dengan bobot molekul rantai $\alpha_{1} 130,33 \mathrm{kDa}$. Komposisi asam amino didominasi oleh asam amino glisin, asam glutamat, prolin dan alanin.

\section{DAFTAR PUSTAKA}

Abedin, M.D.Z., Karim, A.A., Ahmed, F., Latif, A.A., Gan, C.Y., Ghazali, F.C., W., \& Sarker, M.Z.I. (2013). Isolation and characterization of pepsin-solubilized collagen from the integument of sea cucumber (Stichopus vastus). J Sci Food Agric, 93(5),1083-8. doi: 10.1002/ jsfa.5854.

Aberoumand, A. (2012). Comparative Study Between Different Methods of Collagen Extraction from Fish and its Properties. World Applied Sciences Journal, 16 (3), 316-319.

Alhana, Suptijah, P. \& Tarman, K. (2015). Ekstraksi dan Karakterisasi Kolagen dari Teripang gamma. Jurnal Pengolahan Hasil Perikanan Indonesia, 150-61. DOI: 10.17844/jphpi.2015.18.2.150

Andiristanti WA. (2012).Uji Manfaat Ekstrak Kolagen Kasar dari Teripang Stichopus Hermanii Sebagai Bahan Pelembab Kulit. Universitas Indonesia : Tesis

[AOAC] Association of Official Analytical Chemist. (2005). Official Methods of Analysis. Association of Official Analytical Chemist Inc. Washington,DC.

Aydin, M., Sevgili, H., Tufan, B., Emre, Y., \& Ko se, S. (2011). Proximate Composition and Fatty Acid Profile of Three Different Fresh and Dried Commercial Sea Cucumbers From Turkey. Int J. Food Sci Tech, 46, 500-508

Barth, A. (2000). The Infrared Absorption of Amino Acid Side Chain. Review. Progress in Biophysics and Molekuler Biology, 74, 141-173.

Bordbar, S., Anwar F., \& Saari N. (2011). High-value components and bioactives from sea cucumbers for functional foods-a review. Mar Drugs. 9(10), 1761805. doi: $10.3390 / \mathrm{md} 9101761$.

Coates, J. 2000. Interpretation of infrared spectra. A practical approach. Di dalam Meyers R.A. (Ed.) Encyclopedia of Analytical Chemistry. Chichester: John Wiley \& Sons Ltd. Pp. 10815-10837

Cui, F.X., Chang, H.X., Zhao, J.L., Yong, Q.Z., Ping, D., Xue, Y.F., Xin, G. (2007). Characterization and subunit composition of collagen from the body wall of sea cucumber (Stichopus japonicus). Food Chemistry 100 : 1120-1125

Doyle, B. B., Bendit, E. G., \& Blout, E. R. (1975). Infrared spectroscopy of collagen and collagen-like polypeptides. Biopolymers, 14, 937-95

Fawzya, Y.N. , Januar, H.I., Susilowati, R., \& Chasanah, E. (2015). Chemical composition and fatty acid profile of some Indonesian sea cucumbers. Squalen Bull. of Mar. \& Fish. Postharvest \& Biotech, 10 (1), 27-34

Forghani, B., Ebrahimpour, A., Bakar, J., Hamid, A.A., Hassan, Z. \& Saari, N. (2012). Enzyme Hydrolysates from Stichopus horrens as a New Source for Angiotensin-Converting Enzyme Inhibitory Peptides. Evidence-Based Complementary and Alternative Medicine, Article ID 236384, 9 pages. http://dx.doi.org/ $10.1155 / 2012 / 236384$

Haider, M. S., Sultana, R. S., Jamil, K., Lakhte, Zehra, Tarar, M., Shirin, K., \& Afzal, W. (2015). A study on proximate composition, amino acid profile, fatty acid 
profile and some mineral contents in two species of sea cucumber. J Anim Plant Sci, 25(1):168-175

Hartati, R., Widianingsih, \& Fatimah, U. (2015). ReDeskripsi Teripang Stichopus hermanii Dari Kepulauan Karimunjawa Melalui Analisa Morfologi, Anatomi dan Spikula (Ossicles). Jurnal Kelautan Tropis, 18(2),70-75.

International Trade Centre. (2016). List of products imported by Indonesia detailed products in the following category: 35 Albuminoidal substances; modified starches; glues; enzymes, 2011-2015. In Trademap. International Trade Statistics. http:// w w w. t r a d e m a p.org/trade st a t/ Product_SelCountry_TS.aspx.

Jamilah, B., Umi Hartina, M. R., Mat Hashim, D. \& Sazili, A. Q. (2013). Properties of collagen from barramundi (Lates calcarifer) skin. International Food Research Journal, 20(2), 835-842 .

Khirzin, M.H., Sukarno, Yuliana, N.D., Fawzya, Y.N. \& Chasanah, E. (2015). Aktivitas inhibitor enzim pengubah angiotensin (ACE) dan antioksidan peptida kolagen dari teripang gamma (Stichopus variegatus). J. Pascapanen dan Bioteknol, Kelautan dan Perikanan 10(1), 27-35.

Kiara Indonesia. 2015. Perdagangan Teripang. Bulletin Kabar Bahari, edisi Mei-Juni 2015. p. 4-9.

Kittiphattanabawon, P., Benjakul, S., Visessanguan, W., \& Shahidi, F. (2010). Isolation and characterization of collagen from the cartilages of brownbanded bamboo shark (Chiloscyllium punctatum) and blacktip shark (Carcharhinus limbatus). LWT - Food Science and Technology, 43, 792-800.

Kong, J., \& Yu, S. (2007). Fourier transform infrared spectroscopic analysis of protein secondary structures. Acta bioch bioch sin, 39(8), 549-559

Laemmli, U.K. (1970). Cleavage of structural protein during the assembly of the head of bacteriophage T4. Nature, 227, 680-685.

Liu, Z., Alexandria, C.M., Oliveira., \& Su, Y.C. (2010). Purification and characterization of pepsin solubilized collagen from skin and connective tissue of giant red sea cucumber (Parastichopus californicus). Agriculture Food.Chemistry, 58, 12701274.

Mahboob, S. (2015). Isolation and characterization of collagen from fish waste material- skin, scales and fins of Catla catla and Cirrhinus mrigala. J Food Sci Technol, 52(7), 4296-4305. doi: 10.1007/s13197014-1520-6.

Nazeer, R.A., Kavitha, R. Ganesh, Naqash, J.S.Y., Kumar, N.S.S. \& Ranjith, R. (2014). Detection of collagen through FTIR and HPLC from the body and foot of Donax cuneatus Linnaeus, 1758. J Food Sci Technol, 51(4), 50-55. doi: 10.1007/s13197-011-0539-1.

Nurhayati, Tazwir, \&Murniyati. (2013). Ekstraksi dan Karakterisasi Kolagen Larut Asam dari Kulit Ikan Nila (Oreochromis niloticus). Komunikasi ringkas. Jurnal Pasca panen dan Bioteknologi Kelautan dan Perikanan, 8(1), 85-92.

Park, S.Y., Hee, K.L., Seogjae, L., Hyeong, C.H., Somi, K.C., \& Moonjae, C. (2012). Pepsin solubilized collagen (PSC) from red sea cucumber (Stichopus japonicas) regulates cell cycle and fibronectin synthesis in HaCaT cell migration. Food chemistry, 132, 487-492

Peng, Y., Glattauer, V., Werkmeister, J.A. \& Ramshaw, J.A.M. (2004), Evaluation for collagen products for cosmetic application. International Journal of Cosmetic Science, 26(6), DOI: 10.1111/j.14672494.2004.00245_2.

Rasyid, A. (2014). Potensi pemanfaatan teripang Stichopus variegatus sebagai suplemen makanan. Oseanologi dan Limnologi di Indonesia, 40(2).

Schmidt, M. M., Dornelles, R. C. P., Mello, R. O., Kubota, E. H., Mazutti, M. A., Kempka, A. P. \& Demiate, I. M. (2016). Collagen extraction process. Mini Review. International Food Research Journal, 23(3), 913-922.

Singh, P., Benjakul, S., Maqsood, S., \& Kishimura, H. (2011). Isolation and characterization of collagen extracted from the skin of striped catfish (Pangasianodon Hypophthalmus). Food chemistry, 124, 97-105.

Silva, T.H., Moreira-Silva, Marques, A.L.P., Domingues, A., Bayon, I. \& Reis.L. (2014). Marine Origin Collagens and Its Potential Applications. Mar Drugs. 2014 Dec; 12(12): 5881-5901. doi: 10.3390/md12125881

Siddiqui, Y.D., Arief, E.M., Yusoff, A., Suzina, A.H., Abdullah, S.Y. (2013). Isolation of pepsin solubilized collagen (PSC) from crude collagen extracted from body wall of sea cucumber (Bohadschia spp.). Int $J$ Pharm Sci. 5(2):555-559.

Tuwo, A. (2004). Status of Sea Cucumber Fisheries and farming in Indonesia. In Advances in Sea Cucumber Aquaculture and Management; Lovatelli, A., Conand, C., Purcell, S., Uthicke, S., Hamel, J.-F., Mercier, A., Eds.; FAO Fisheries Technical Paper No. 463; FAO: Rome, Italy, pp. 49-55.

Vergara, W., \& Rodríguez, A. (2016). Nutritional Composition of Sea Cucumber Isostichopus sp. Natural Resources, 7, 130-137. http://dx.doi.org/10.4236/ nr.2016.73013.

Yusida, A. (2016). Formulasi Sediaan Krim Berbasis Nanokolagen Teripang gamma (Stichopus variegatus). Skripsi. Fakultas Perikanan dan IImu Kelautan, Institut Pertanian Bogor. 36p.

Zhang, Y., Liu, W., Li, G., Shi, B., Yu, Q. \& Wu, X. (2007). Isolation and partial characterization of pepsinsoluble collagen from the skin of Grass Carp (Ctenopharyngodon idella). Food Chemistry, 103, 906 - 912 . ht t p://dx.doi.org/10.1016/ j.foodchem.2006.09.053.

Zhong, M., Chen, T., Hu, C., \& Ren, C. (2015). Isolation and characterization of collagen from body wall of sea cucumber Stichopus monotuberculatus. Journal of food science, 80(4), c1-c9. doi: 10.1111/17503841.12826 .

Zhong, Y., Khan, M.A., \& Shahidi, F. (2007). Compositional Characteristics and Antioxidant Properties of Fresh and Processed Sea Cucumber (Cucumaria frondosa). J. Agric. Food Chem. 2007, 55, 1188-1192. 